DOI: $10.19195 / 2353-8546.4 .5$

\title{
Pokoleniowe różnice $w$ artystycznym obrazowaniu doświadczenia totalitarnej przeszłości w czeskim teatrze najnowszym
}

Generational differences in artistic representations of the experience of totalitarian past in the new Czech theatre. The article presents an analysis of a number of Czech performances from the years 2007-2013 on the topic of the communist era and reflecting on the changes that have occurred over the past 25 years. Selected directors belong to three generations of artists: the ones already creating in the 1960s, the ones debuting just before or just after the Velvet Revolution and the ones beginning their career in 2000. The comparison of performances produced within a short time clearly shows the differences, both aesthetic and ideological, in the method of recognizing similar issues by the authors growing up in a completely different socio-political conditions. Works of the oldest generation, using conventional theatrical means, reveal the strongest judgmental tendencies, the need to show the ambiguous choices in black and white colors. The average generation contend with the legend of past years, asking difficult questions about the impact of the past on the shape of collective identity. The youngest generation, however, intentionally emphasize that their knowledge about communism is mediated, which encourages them to analyze the history and memory of their families in search of their own roots.

Keywords: Czech theatre, totalitarianism, memory, identity, generation

Generační rozdíly v uměleckém zobrazování zkušenosti totalitární minulosti v nejnovějším českém divadle. Př́íspěvek obsahuje analýzu několika českých představení z let 2007-2013, jejichž tématem se stalo období komunismu a reflexe nad proměnami posledních 25 let. Vybraní režiséři patří ke třem generacím umělců:

* Adres do korespondencji: Instytut Filologii Słowiańskiej UAM w Poznaniu, ul. Aleksandra Fredry 10, 61-701 Poznań. E-mail: czachor.sylwia@gmail.com. 
jedni inscenovali dlouho před rokem 1989, druzí debutovali krátce po sametové revoluci, zatímco třetí zahájili kariéru v roce 2000. Soubor představení vzniklých v malém časovém rozpětí výrazně ukazuje jak estetické, tak světonázorové rozdíly ve způsobu uchopení podobné tematiky autory, kteří vyrůstali ve zcela odlišných společensko-politických podmínkách. Díla nejstarší generace pomocí konvenčních divadelních prostř̌edků projevují nejsilnější tendence posuzovat a odsuzovat, nutnost ukázat nejednoznačné volby v černo-bílých barvách. Stř̌ední generace se poměřuje s legendami minulých dob, pokládá obtižné otázky po vlivu minulosti na podobu kolektivní identity. Nejmladší tvưrci pak vědomě zdůrazňují, že jejich znalost komunismu je zprostředkovaná, což je vede k analyzování historie a rodinné paměti při hledání vlastních kořenů.

Klíčová slova: české divadlo, totalitarismus, pamět, identita, generace

Nauki społeczne wypracowały wiele bardzo różnych definicji pokolenia, używając kryteriów biologicznych albo kulturowo-historycznych. W niniejszym artykule wykorzystane zostały pojęcia sformułowane w ramach orientacji kulturowej, która, w przeciwieństwie do historycznej, nie traktuje daty urodzenia jako przesądzającej o przynależności do danej generacji. Za główny wyznacznik pokolenia przyjmuje się natomiast wspólnotę „myśli i zachowań stanowiących reakcję na "nową sytuację historyczną", [...] nie proste następstwo wydarzeń historycznych"1. Przyjęte założenie pozwala uwypuklić fakt, iż dojrzewanie w danych warunkach polityczno-społeczno-ekonomicznych i obowiązującym systemie wartości ukształtowało sposób postrzegania konkretnych zdarzeń historycznych.

Przedstawione w niniejszym artykule spektakle powstały mniej więcej w tym samym czasie: w latach 2007-2013. Po tym, jak w latach dziewięćdziesiątych czescy reżyserzy programowo uciekali od teatru politycznego ${ }^{2}$, rok 2000 przynosi całkowity zwrot w myśleniu o potrzebie istnienia spektakli zaangażowanych, które od tej chwili zaczynają powstawać masowo. Omówione dalej inscenizacje zapisały się w historii czeskiego teatru — otrzymały ogólnonarodowe nagrody albo poświęcono im wiele uwagi w publikacjach specjalistycznych. Z tego względu, a także w związku z ograniczeniami objętościowymi artykułu pominięty został szczegółowy opis inscenizacji i ocena walorów artystycznych. Tym samym cała uwaga skupia się na streszczeniu ich linii myślowej oraz na uwypukleniu pokoleniowych różnic w obrazowaniu doświadczenia totalitarnej przeszłości. Wszystkie przywołane przedstawienia powracają do wycinków z czeskiej historii II połowy XX wieku i spoglądają na nie z perspektywy teraźniejszości. Jednak tworzący je reżyserzy należą do różnych pokoleń, uformowanych bądź przez odmienne oblicza komunizmu, bądź już przez

${ }^{1}$ W. Wrzesień, Czy pokoleniowość nam się nie przydarzy? Kilka uwag o współczesnej polskiej młodzieży, „Nauka” 2007, nr 3, s. 137.

210 let po..., zapis dyskusji, „Svět a divadlo” 1999, nr 6, s. 6-19. Por. J. Kerbr, Politické divadlo také u nás, „Svět a divadlo” 2000, nr 1, s. 91-96 oraz wiele innych artykułów i zapisów rozmów opublikowanych na łamach tego czasopisma w latach dziewięćdziesiątych. 
rzeczywistość postkomunistyczną, doświadczając totalitarnej przeszłości w sposób zapośredniczony przez media i opowieść poprzednich generacji.

\section{Pokolenie „listopadowe" i „polistopadowe”}

Martin J. Švejda w jednym z numerów czasopisma teatralnego „Svět a divadlo” dokonuje pokoleniowego podziału najbardziej znanych czeskich reżyserów w zależności od daty debiutu, uznając za czynnik spajający ich w jednorodną grupę społeczną wspólnotę wypracowanej poetyki oraz wyznawanego w obrębie sztuki systemu wartości ${ }^{3}$. Istotnym faktem różnicującym twórczość artystów kolejnych pokoleń jest bowiem wyraźny podział na estetyczne dekady w teatrze czeskim II połowy XX wieku, będący w dużej mierze rezultatem sytuacji politycznej. Lata sześćdziesiąte to w Czechach rozkwit tzw. teatru małego (małe formy sceniczne, intymna przestrzeń, autentyczność) ${ }^{4}$, w latach siedemdziesiątych pojawia się myślenie o teatrze jako o dziele kolektywnym (teatr autorski, praktyki postdramatyczne, pozawerbalne) ${ }^{5}$, a z kolei lata osiemdziesiąte charakteryzuje dominacja teatru wizualnego, często amatorskiego, oraz powstawanie pierwszych spektakli postmodernistycznych ${ }^{6}$. Dopiero ostatnie, wolne dziesięciolecie XX wieku przynosi nadzwyczaj bogaty konglomerat wszystkich poprzednich estetyk ${ }^{7}$, w znacznie mniejszym stopniu obecny po 2000 roku, ale nadal uchwytny, zwłaszcza w przedstawieniach sięgających do wspólnej traumatycznej przeszłości.

Jednym z najbardziej rozpoznawalnych przedstawicieli pokolenia debiutującego około roku 1989 jest Vladimír Morávek — uznawany za eksperymentatora, który

${ }^{3}$ M.J. Švejda, Přirozený vývoj? 90. léta v českém činoherním divadle, „Svět a divadlo” 2002, nr 4, s. $12-19$.

${ }^{4}$ Zob. T. Lazorčáková, Čas malých divadel, Olomouc 1996, s. 18-20.

${ }^{5}$ Zob. J. Kovalčuk, Téma: autorské divadlo, Brno 2009.

${ }^{6}$ Zob. J. Dvořak, Vizuálni divadlo v českých zemích a kontext osmdesátých let. Co mohou dnešnímu uměleckému radikálovi nabídnout divadelní „osmdesátky”, [w:] Divadlo a interakce V, red. M. Klíma et al., Praha 2011, s. 117-152.

7 Stało się tak ze względu na to, iż nowa sytuacja polityczna pozwoliła na powrót artystów odrzuconych przez poprzedni reżim oraz powszechną potrzebę ich rehabilitacji. Wielu z uznanych wcześniej reżyserów otrzymało w ten sposób stanowiska dyrektorów teatrów lub wsparcie finansowe pozwalające na odtworzenie zamkniętych przez władze komunistyczne scen i kontynuowanie poetyki wypracowanej w latach sześćdziesiątych i siedemdziesiątych. Z drugiej strony najmłodsi reżyserzy zdobyli już uznanie publiczności zupełnie nowym spojrzeniem na teatr i coraz intensywniej zaznaczali swoją obecność na czeskich scenach, korzystając też z nowych osiągnięć technologicznych. Według Švejdy w latach dziewięćdziesiątych współistniało sześć reżyserskich pokoleń (wyznaczonych ze względu na okres debiutu): powojenne (m.in. Otomar Krejča, Jaromír Pleskot, Jan Grossman), lat pięćdziesiątychsześćdziesiątych (m.in. Ladislav Smoček, Jan Kačer, Jan Schmid), lat sześćdziesiątych-siedemdziesiątych (m.in. Petr Scherhaufer, Eva Talská, Ivan Rajmont, Arnošt Goldflam), lat osiemdziesiątych (m.in. Jan Nebeský, Jan Antonín Pitínský, Hana Burešová, Petr Lébl), „listopadowe” (m.in. Michal Dočekal, Vladimír Morávek, Jiří Pokorný) i wreszcie „polistopadowe” (m.in. Daniel Hrbek, Martin Čičvák). M.J. Švejda, op. cit. 
w sposób zarówno atrakcyjny, jak i prowokacyjny wypowiada się na temat czeskiego społeczeństwa ${ }^{8}$. Charakterystycznym rysem jego twórczości jest obnażanie brzydoty współczesnego świata, w którym nastąpiła dewaluacja wartości, moralny rozkład, bezcelowe poszukiwanie sensu życia i własnej roli w świecie. Balansując na granicy zabawy i grozy, w groteskowym zwierciadle wyśmiewa oraz krytykuje czeską ksenofobię, małostkowość, prezentuje największe lęki, frustracje i problemy swojego czasu?.

Podobnie czyni w trwającym 3 lata projekcie „Perwersja w Czechach” (Perverze v Čechách, 2007-2009), w którego skład wchodzą trzy sztuki. Pierwsza, oparta na filmie Miloša Formana, inscenizacja Miłość blondynki (Lásky jedné plavovlásky aneb Př́běh ze 60. let, premiera 16 listopada 2007) przedstawia lata sześćdziesiąte jako czas bezkrytycznej nadziei i ogromnej przepaści między wyobrażeniem rzeczywistości a jej realnym obliczem. W kilkunastu sugestywnych obrazach reżyser ewokuje legendę złotych lat sześćdziesiątych i jednocześnie z nią polemizuje, przedstawiając, jak wiele z zapamiętanej wówczas wolności było tylko naiwnością i iluzją. Jako drugi Morávek zaprezentował kolaż różnych tekstów Václava Havla, przeplatany fragmentami książki Mariusza Szczygła Gottland, zatytułowany Cyrk Havel (Cirkus Havel aneb My všichni jsme Lád’a, premiera 7 listopada 2008). W inscenizacji tej relatywizm moralny Czechów, przedstawiony jako cecha narodowa przejawiająca się w dokonywanych przez nich wyborach $z$ lat siedemdziesiątych i osiemdziesiątych (co stanowi treść pierwszej części spektaklu), zestawiony został z postawą Czechów po upadku komunizmu. Autorska wizja nie napawa optymizmem - według niej Czesi na początku XXI wieku niezmiennie kierują się lękiem i niepewnością, brakuje im jasno wytyczonych wartości moralnych i duchowych, a ponadto przepełnia ich rozczarowanie z niespełnionych obietnic. Jako trzecią część cyklu Morávek zrealizował współczesną sztukę Davida Drábka (Náměstí bratří Mašínů, 2009) pod zmienionym tytułem: Czeskie morze (České moře, premiera 7 listopada 2009), przedstawiając tym samym tęsknotę Czechów za czymś, czego mieć nie mogą. W programie reżyser dopowiada, że kluczowym zagadnieniem poruszanym w inscenizacji jest pytanie $\mathrm{o}$ istnienie jakiejkolwiek nadziei $\mathrm{w}$ dwadzieścia lat po aksamitnej rewolucji.

Tak pomyślany cykl prezentuje tożsamość, moralność i system wartości Czechów, oparty na podwójnym rozczarowaniu - pierwsze przyszło wraz z praską wiosną, która pogrzebała iluzje lat sześćdziesiątych, drugie pojawiło się kilka lat po 1989 roku w wyniku braku oczekiwanych zmian na lepsze. Nie ma tu jednak odniesień do niedokończonych czy nietrafionych transformacji ekonomicznych, wręcz przeciwnie - do negatywnych wniosków prowadzi analiza współczesnej duchowości i moralności narodu.

${ }^{8}$ H. Hložková, Vznik reřijního rukopisu čili Vladimír Morávek v Divadle Husa na provázku (19891995), [w:] Theatralia: Sborník prací filozofické fakulty brněnské univerzity, red. J. Gajdoš, A. Jochmanová, Z. Brandejská, Brno 2005, s. 207.

${ }_{9}$ Zob. studia zawarte w tomie Vladimír Morávek. U nás nudou neumřete, red. L. Němečková et al., Praha 2004. 
Istnieje bardzo duże podobieństwo między opisanym cyklem Morávka a spektaklami Jana Mikuláška, reżysera, który debiutował już w latach dziewięćdziesiątych. Śledząc jego twórczość, można dostrzec, że w ostatnich latach interesowała go przede wszystkim czeska historia XX stulecia. Vladimír Mikulka nazwał tę linię przedstawień „sceptycznym przewodnikiem po wieku XX” ${ }^{10}$. Należą do nich między innymi adaptacje Gottlandu Mariusza Szczygła oraz Patrika Ouředníka próby ujęcia w całość europejskiej dwudziestowiecznej historii w postmodernistycznej prozie Europeana: zwięzła historia XX wieku (Europeana. Stručné dějiny dvacátého věku, 2001, wyd. polskie 2004). Wpisują się tu również dwa przedstawienia z planowanego tryptyku przybliżającego kolejne totalitarne dziesięciolecia: Złote lata 60. (Zlatá šedesátá aneb Deník Pavla J., premiera 20 września 2013) oraz Szare lata 70. (Šedá sedmdesátá aneb Husákovo ticho, premiera 1 listopada 2013). Oba zrealizowane w 2013 roku sięgają zatem do identycznego wycinka czasowego komunistycznej rzeczywistości, co spektakle Morávka i w podobny sposób demitologizują lata sześćdziesiąte oraz prezentują moralny marazm czasów normalizacji.

Mająca za podstawę bardzo subiektywne i krytyczne Dzienniki Pavla Juráčka (Deníky, 2003) inscenizacja Złote lata 60. w ironicznym kontraście do tytułu buduje depresyjny obraz rzeczywistości tamtych lat o spowolnionym rytmie przyciemnionych obrazów. Przewija się w niej wyrażone w tekście literackim zniesmaczenie niezrozumiałym optymizmem i powszechnym uwielbieniem ikon czeskiej popkultury, niechęć wobec alkoholowych libacji i seksualnych ekscesów, wreszcie bezlitosna krytyka ślepego na wszystko społeczeństwa. Juráček wyraża przekonanie, że jako jedyny nie może pozbyć się świadomości nadchodzącej katastrofy, ponieważ naród nie zdoła uciec przed fatalnymi następstwami iluzji, którą się karmi ${ }^{11}$. Pojawia się tutaj apokaliptyczna wizja przyszłości — oddychamy zanieczyszczonym powietrzem, ludzka mowa staje się niezrozumiała, a świat - swoją okropną, surową karykaturą. Wizja ta urzeczywistni się w latach siedemdziesiątych, co wymownie i bardzo okrutnie przedstawia drugie dzieło niedokończonego tryptyku Mikuláška. Normalizacyjna banalność, marazm i moralna chwiejność, zgodnie z czeską tradycją czarnego humoru i groteski, ukazane są jako seria barwnych gagów bez pointy, ale za to z bardzo kontrowersyjnym momentem kulminacyjnym. Główną bohaterką drugiej części inscenizacji reżyser uczynił bowiem Olgę Hepnarovą, która w 1973 roku, kierując ukradzionym autobusem, celowo wjechała na przystanek tramwajowy, zabijając ośmioro ludzi, za co została powieszona jako ostatnia kobieta-ofiara kary śmierci w Czechach. Na pustej białej scenie Hepnarová sama opowiada swoją historię, mówiąc jak rodzina i napotkani przez nią obcy ludzie doprowadzili ją do stanu nienawiści wobec całej ludzkości. Zbrodniarka staje się tym samym ofiarą społeczeństwa ogłupiałego przez system, któremu się podporządkowało. Czeska publicz-

${ }^{10}$ V. Mikulka, Cosi na úrovni okusování nehtư. Odvrácená strana zlatých šedesátých let, „Svět a divadlo" 2013, nr 3, s. 63.

${ }^{11}$ Ibidem, s. 56-64. 
ność za kontrowersyjne uznała przede wszystkim fakt wykorzystania w programie inscenizacji fragmentów książki Vratislava Effenbergera Republiku a varlata (2013) zestawiającej postać Hepnerovej z Janem Palachem i dowodzącej, że swoim czynem zaprotestowała nie przeciwko aktualnej sytuacji politycznej, lecz przeciwko ludzkiemu tchórzostwu, obłudzie i chciwości ${ }^{12}$.

\section{Pokolenie lat sześćdziesiątych-siedemdziesiątych}

Oba spektakle Mikuláška powstały w praskim Divadle Na zábradlí, w którym reżyser objął funkcję szefa artystycznego w sezonie 2013/2014 - teatrze posiadającym długą i bogatą tradycję sceny zaangażowanej. Tutaj swoją premierę miała także inscenizacja dramatu Milana Uhdego Cud w czarnym domu (Zázrak v černém domé, 2004, premiera 9 marca 2007) w reżyserii Juraja Nvoty. Sztuka ta, uznana za najlepszą zrealizowaną na scenie w 2007 roku $^{13}$, powtarza i przetwarza motywy dramatów napisanych przez Uhdego już w latach osiemdziesiątych (zwłaszcza Velice tiché Ave, $1990^{14}$ ). Dramatopisarz ten zresztą w czasach komunistycznych w znacznej mierze wpłynął na kształt ówczesnego teatru ${ }^{15}$.

Bohaterem Cudu w czarnym domu jest współczesna czeska rodzina kryjąca wiele tajemnic, odkrywanych retrospektywnie. Pełna wątków autobiograficznych historia obrazuje moralne dylematy ciążące na poszczególnych członkach rodu naznaczonego fatum niemoralnych wyborów kolejnych pokoleń. Ciężar przeszłości koncentruje się na konflikcie dwóch braci, którzy kilkanaście lat po upadku komunistycznego reżimu, noszą w sobie nadal urazy spowodowane wyborem odmiennych ścieżek - dysydenta i kolaboranta. W spektaklu obaj zostają zaprezentowani w czarno-białych barwach jako zupełne przeciwieństwa. Posłuszny komunistom Ivan to prosty, niewykształcony i nieokrzesany mężczyzna, który również w małżeństwie powiela tradycyjne, stereotypowe wzorce. Dysydent Dušan jest zdecydowanie lepiej wykształcony, jego żona to równorzędna partnerka, a on sam wydaje się osiągnąć sukces w wolnym kraju. Nosi w sobie jednak wiele pretensji wobec postawy całej rodziny, która, obawiając się represji ze strony władzy, wydziedziczyła go z praw

12 J. Janatka, Opravdu obhajoba vraždy? (aneb Hepnarová na Zábradlí), „Divadelní noviny” 23.01.2014, http://www.divadelni-noviny.cz/opravdu-obhajoba-vrazdy-aneb-hepnarova-na-zábradlí [dostęp: 5.11.2014]. Por. J. Kolář, Všedně krutá a zlá léta sedmdesátá, „Divadelní noviny” 9.12.2013, http://www.divadelni-noviny.cz/seda-sedmdesata-aneb-husakovo-ticho-recenze [dostęp: 5.11.2014].

13 Zob. Ankéta kritiků, „Svět a divadlo” 2008, nr 2, s. 8-10. Krytycy, uzasadniając swój wybór, podkreślali przede wszystkim, że sztuka o czarnym domu wypełniła dotkliwą lukę w czeskim dramatopisarstwie po 2000 roku, poddając ogólnej refleksji czasy komunizmu. Por. M.J. Švejda, Československé jaro Na zábradlí po třetí, „Svět a divadlo” 2007, nr 5, s. 122.

14 Por. Z. Hořínek, Milan Uhde - od ironie ke katarzi, „Svět a divadlo” 1996, nr 2, s. 152-158.

15 Za jego najważniejsze dzieła uważa się: satyryczno-polityczną sztukę Král Vávra z 1964 roku (Večerní Brno, 1964), absurdalny monodram Výběrčí z 1966 roku (reż. Petr Lébl, 1990) oraz Velice tiché Ave z 1981 roku (reż. Jana Knitlová, 1990). 
do „czarnego domu”, a teraz uparcie milczy, starając się zachować pozory normalności i wzajemnej miłości. Dušan jednak wymaga od swoich bliskich przyznania się do winy, żąda wyjaśnień i sprawiedliwości, które na koniec otrzymuje.

Uhde i Nvota tworzą na scenie posttotalitarny, wręcz perwersyjnie czysty świat (dom przypomina rażące wszechobecną białością pudełko-kryjówkę, postaci też pojawiają się ubrane w absolutną biel), w którym nawet najbliżsi mają na sumieniu jakąś niewygodną tajemnicę czy nawet zbrodnię. Twórcy z jednej strony starają się ukazać motywy potępianych z perspektywy czasu wyborów, z drugiej zaś domagają się ich ujawnienia, przyznania się do winy. To, co bowiem wydaje się najmroczniejsze w posttraumatycznej rzeczywistości, to tworzenie pozorów, dążenie do zapomnienia, do życia jakby przeszłości nie było, zamykania się w wyimaginowanym świecie, $\mathrm{w}$ idealnie białych i czystych czterech ścianach skrywających czarną przeszłość. A widz wychodzi z teatru z przekonaniem, że choć niełatwo jest ocenić postępowanie kogokolwiek, kto próbował przetrwać totalitarny reżim, należy jednak pamiętać i z perspektywy dzisiejszych wartości każdemu jego winy przypomnieć. Dramatopisarz i reżyser stoją na stanowisku, że tylko prawda o przeszłości może być oczyszczająca, i zdają się wierzyć, że prawda jest tylko jedna.

\section{Szczęśliwe pokolenie ${ }^{16}$}

Omawiane wyżej spektakle należą do teatru dramatycznego w jego trzech różnych postaciach. W obliczu rozwoju nowych mediów i technologii oraz wymieszania się rozmaitych typów sztuk współtworzących widowisko, w czeskim teatrze po roku 2000 coraz wyraźniejszy staje się nurt teatru alternatywnego. Historia, najczęściej w skali mikro, zawężona do rodziny czy konkretnego miejsca, jest jednym z dominujących tematów podejmowanych przez najmłodsze pokolenie reżyserów.

Podobnie jak w spektaklu Cud w czarnym domu, pamięć rodziny oraz to, w jaki sposób przodkowie wpływają na naszą tożsamość, stanowi podstawę performance'u Chmury, rodzinna archeologia (Mraky, rodinná archeologie, premiera 20 października 2011) grupy Handa Gote Research \& Development. Inscenizacja jest kolażem osobistych wspomnień performerki Veroniki Švábovej — zatrzymanych zarówno w starych fotografiach, listach i przedmiotach, jak i w zapamiętanych opowieściach, muzyce słuchanej z babcią, przekazywanych z pokolenia na pokolenie przepisach kulinarnych, czy wreszcie w ciele, w gestach. Charakterystyczne dla działalności Handa Gote jest wykorzystanie nowych technologii, dzięki którym tworzą pokazy z pogra-

${ }^{16} \mathrm{~W}$ przeciwieństwie do nazw pozostałych pokoleń zaczerpniętych ze wspomnianego studium M. Švejdy, określenie „szczęśliwe pokolenie” pochodzi z książki o takim właśnie tytule, opisującej artystyczną działalność młodych czeskich reżyserów, debiutujących po 2000 roku. Zob. Štastná generace. Režiséri z alterny, red. M. Ljubková et al., Praha 2013. 
nicza teatru, wideo-artu, performance’u i tańca ${ }^{17}$. Tak jest również w przypadku inscenizacji Chmury - działaniom aktorki towarzyszą nowoczesne urządzenia nagrywające i odtwarzające jej ruch na ogromnym płótnie, tworzące wymowną metaforę działania pamięci i upływu czasu. Nowe media użyte w inscenizacji podkreślają, że mamy do czynienia z zapisem przeszłości, z narracją o zdarzeniach, a nie z samymi zdarzeniami. Artystka nie ukrywa, że prezentuje bardzo subiektywny i osobisty wybór z dziejów czterech pokoleń własnej rodziny. Te różne historie, dotyczące także kontrowersyjnych wyborów i powikłanych losów, pojawiają się w strzępach, w dowolnej kolejności - tak, jak chaotycznie przywołuje je pamięć. Poprzez zestawienie dobrych, złych, tragicznych i śmiesznych wydarzeń z życia przodków artystka stara się pokazać, jak rodzinna przeszłość wpłynęła na to, kim ona jest dzisiaj. Nie ocenia ani nie moralizuje, próbuje tylko zrozumieć, co z nich w niej pozostało. Z humorem i dystansem składa skrawki tego, czego się o nich dowiedziała, czego się od nich nauczyła, emocji, których przy nich doznała, wspomnień, rodzinnych tajemnic i tego, co najtrudniej uchwytne, a chyba dla artystki najważniejsze - co zapisało się w ciele.

Spektakl Chmury powstał w wyniku pracy nad tzw. little stories, które przez odkrywanie historii pojedynczych ludzi stawiają zwierciadło wielkiej historii. W jednym z poprzednich pokazów o tytule Ekran (Ekran - found fotage kino, premiera kwiecień 2006) artyści za pomocą minimalistycznych działań aktorskich i muzyki starali się odtworzyć życiorysy osób ze zdjęć znalezionych na śmietniskach czy na strychach ${ }^{18}$. Tym samym Handa Gote wpisuje się w trend dominujący w najnowszym czeskim teatrze alternatywnym, który poprzez połączenie prezentacji obiektywnych faktów z osobistym do nich stosunkiem stanowi niezmiernie ciekawą wersję teatru dokumentalnego, przedstawiającego „rovnováhu vnější, dokumentární pravdy s pravdou vnitřní, uměleckou" - jak zauważa czeski teatrolog, Karel Král ${ }^{19}$. Dzięki temu widowiska nie sprawiają wrażenia ideologicznych, wręcz przeciwnie, mają znamiona egzystencjalnych rozważań nad istotą człowieczeństwa.

Opisy kilku innych tego typu projektów znaleźć można w jednej z najświeższych publikacji wydawnictwa Praska scena - Szczęśliwa generacja (Štastná generace. Režiséri $z$ alterny, 2014). Zdecydowana większość artystycznych działań reżyserów uznanych za najwybitniejszych przedstawicieli swojego pokolenia to teatr zaangażowany społecznie, którego podstawę stanowią autentyczne, intymne wspomnienia rozmaitych osób. Między innymi w Osobistej anamnezie (Osobní anamnéza, premiera

17 D. Melichar, $4+4=8$ 1/2 (No. 5), „Divadelní noviny”, 21.10.2011, http://www.divadelni-noviny.cz/4-4-8-12-no-5 [dostęp: 30.10.2014] oraz V. Hulec, Divadelní události 2012, „Divadelní noviny” 31.12.2012, http://www.divadelni-noviny.cz/divadelni-udalosti-2012 [dostęp: 30.10.2014].

18 R. Sikora, Handa Gote / Mraky, „Český rozhlas 3 Vltava” 21.02.2012, http://www.rozhlas.cz/ mozaika/divadlo/_zprava/handa-gote-mraky-recenze-romana-sikory--1021734 [dostęp: 30.10.2014]. Kolejne przedsięwzięcia zespołu (Emily, Houby i Rain Dance) igrały ironicznie przede wszystkim z konwencjami teatralnymi. Zob. ibidem.

19 „[R]ównowagę prawdy zewnętrznej, dokumentalnej i prawdy wewnętrznej, artystycznej” K. Král, Politici zalitují, až když je trefí šlak... Dokumentární divadlo - vzorek Divadelná Nitra 2012, „Svět a divadlo” 2012, nr 6, s. 122. 
23 kwietnia 2009, w ramach projektu Cirkus totality) Petra Tejnorová namawia swoich aktorów do analizy historii własnych rodzin i tym samym opowiedzenia indywidualnej wersji totalitaryzmu, który przecież nie dotknął ich bezpośrednio, a jednak bez wątpienia na nich wpłynął, zarówno przez opowieści przodków, jak i przez kampanię medialną związaną z dziesiątą rocznicą aksamitnej rewolucji ${ }^{20}$.

Te krótkie wzmianki mają jedynie potwierdzić, że teatr w pojęciu „szczęśliwego pokolenia” staje się „syrovým prostředkem ke zkoumání a vyjádření vlastní existence" 21 . Najmłodsi czescy reżyserzy przez artystyczne zagłębianie się w historii poprzednich pokoleń poszukują własnych korzeni, indywidualnej tożsamości. Nie oceniają, nie moralizują, nie analizują nawet, ale prezentują zarówno fakty, jak i ich wypaczone przez wspomnienia wersje, dystansując się od pojęcia prawdy, dobra i zła. Opowieść o czasach komunizmu służy im bowiem przede wszystkim do opowiadania o nich samych.

Średnie pokolenie - „listopadowe” i „polistopadowe”, jak pokazują spektakle Morávka i Mikuláška - znacznie silniej odczuwa ciężar niedawno minionych czasów. Dwaj reżyserzy, kształtujący dziś w dużej mierze obraz czeskiego teatru dramatycznego, reprezentują w swoich inscenizacjach postkomunistyczne niepokoje czeskiego społeczeństwa i w przeciwieństwie do młodszych kolegów, szukają źródeł i znaków tożsamości kolektywnej. Po fali nostalgii za latami sześćdziesiątymi, szczególnie wyraźnej w ostatnim dziesięcioleciu XX wieku, przyszedł według nich czas na demitologizację, pokazanie, że była to „schizofrenní doba plná sebeklamu, křečovitě bezstarostný mejdan v dvojité kleci vlastních iluzí a komunistického režimu"22, co doprowadziło do moralnej katastrofy kolejnej dekady. Jednocześnie oba projekty, a zwłaszcza Perwersja w Czechach stanowią swojego rodzaju nawoływanie do przebudzenia i do refleksji nad wartościami, które ukształtowały i dalej wpływają na czeską tożsamość narodową. Taką funkcję miał spełniać również roczny cykl spotkań z wieloma znaczącymi osobistościami czeskiego życia kulturalnego i politycznego, towarzyszący projektowi Morávka pod hasłem „Świt w Czechach” (Úsvit v Čechách, 2008-2009) ${ }^{23}$.

20 Zob. P. Tejnorová, Velkam tu maj dijary, [w:] Štastná generace, s. 133-157.

21 „[S] urowym narzędziem do badania i wyrażania własnej egzystencji” - J. Rubeš, Petra Tejnorová, péče o polis, [w:] Štastná generace, s. 171.

22 „[S]chizofreniczny czas pełen samozakłamania, spazmatycznie beztroska impreza w podwójnej klatce własnych iluzji i komunistycznego reżimu" - V. Mikulka, Cosi na úrovni okusování nehtü. Odvrácená strana zlatých šedesátých let, „Svět a divadlo” 2013, nr 3, s. 64.

${ }^{23}$ Zapis ostatniego spotkania w ramach tego cyklu, które odbyło się 19 listopada 2009 roku, został opublikowany w książce J. Benda et al., Česká vize — hledání identity 21. století, wyd. 2 rozsz., Brno 2011. W formie krótkich esejów zaproszeni goście wypowiedzieli się na temat: „deset nejdůležitějších hodnot, na kterých by měla stát budoucnost naší společnosti” („dziesięć najważniejszych wartości, na których miałaby oprzeć się przyszłość naszego społeczeństwa”). 
Wreszcie pokolenie, którego młodość przypadła na lata sześćdziesiąte, w swoich inscenizacjach woła o sprawiedliwość, domaga się wykazania każdemu jego win i zasług. Cud w czarnym domu jest dramatem bardzo osobistym, podobnie jak projekty najmłodszej generacji. A jednak fakt, że Uhde doświadczył wydarzeń tamtych lat, a młodzi ludzie znają je jedynie $\mathrm{z}$ opowieści, zdeterminował sposób przedstawienia historii. Veronika Švábová w Chmurach opowiada we własnym imieniu, ale mimo to wprowadza na scenę wielu narratorów - za pomocą ich listów, pamiętanych słów, fotografii. Uhde zaś kryje się za postaciami, ale jego historia ma tylko jednego opowiadacza - tego, który w obliczu terroru i pomimo strachu postępował słusznie. Słusznie według odgórnie narzuconych kryteriów przedstawionych w sztuce jako obiektywne.

Każdy z trzech sposobów artystycznego obrazowania doświadczenia totalitarnej przeszłości zajmuje istotne miejsce w czeskim życiu teatralnym i udowadnia, że nie jest możliwy tylko jeden rodzaj spojrzenia na trudną przeszłość. Także pod względem estetycznym. Wychowany na teatrze lat sześćdziesiątych, w którym komunikacja werbalna i bezpośredniość kontaktu $\mathrm{z}$ widzem stały się podstawą przedstawienia rozumianego jako rodzaj spotkania, Milan Uhde opiera swoją sztukę na słowie i w dużej mierze na własnej biografii, a Juraj Nvota reżyseruje spektakl będący ilustracją dramatu. Obserwatorzy rodzenia się teatru wizualnego lat osiemdziesiątych — Morávek i Mikulášek - tworzą na scenie postmodernistyczne, barwne, groteskowe kolaże tekstów i obrazów. Swoją interpretację komunistycznych lat zawierają nie tyle w jednoznacznym wykładzie, ile w całościowej atmosferze przedstawienia. Wreszcie najmłodsze pokolenie korzysta obficie z nowej technologii, kontrastując z nią fizyczność ludzkiego ciała i pozbieranych „przedmiotów realnych”. Jednocześnie, tworząc kolektywnie i korzystając $\mathrm{z}$ osobistych historii, przetwarzają tradycję czeskiego teatru małego lat sześćdziesiątych i autorskiego lat siedemdziesiątych. 